\title{
Selenium species in vegetables: benefits and toxicity for the body
}

\section{Spesies Selenium pada sayuran: manfaat dan toksisitasnya pada tubuh}

\author{
Alya Luthfiyani Heryadi, Ayu Shalihat, Rimadani Pratiwi, Mutakin* \\ Fakultas Farmasi Universitas Padjadjaran, Jawa Barat, Indonesia \\ *Corresponding author: mutakin@unpad.ac.id
}

\begin{abstract}
Background: Selenium is one of the essential trace elements in various biological body functions. The main source of Selenium in the body is food, one of which is vegetables. Vegetables collect Selenium from the soil which is then converted into various chemical species of Selenium. Such species should be recognized since each has different biological activities.

Objective: The aim of this review was to identify chemical species of Selenium in vegetables as well as the benefits and toxicity for the body.

Methods: Reference searches were done in Pubmed and Google Scholar databases with the keywords "Selenium speciation in plants", "selenite", "selenate", "selenomethionine", "selenocystine", and "semethylselenocysteine"

Results: The results of speciation in several types of vegetables showed that the chemical species of Selenium abundantly found in vegetables were selenomethionine (SeMet), selenocystine (SeCys $\left.\mathrm{S}_{2}\right)$ and semethylselenocysteine (Se-MeSeCys), $\gamma$-glutamyl-Se-methyl-selenocysteine, and inorganic species. Both Selenium-enriched vegetables and the species contained therein have a variety of benefits for the body. However, excessive consumption can also cause toxic effects.

Conclusion: The chemical species of Selenium in vegetables can be either organic or inorganic. Both types of species have different benefits and toxic effects.
\end{abstract}

Keywords: benefits, chemical species, Selenium, toxicity, vegetable

\section{Intisari}

Latar belakang: Selenium merupakan salah satu trace element esensial yang penting pada berbagai fungsi biologi tubuh. Sumber utama Selenium dalam tubuh adalah makanan, salah satunya yaitu sayuran. Sayuran mendapatkan Selenium dari tanah yang kemudian diubah menjadi berbagai spesies kimia Selenium. Spesies kimia Selenium penting untuk diketahui karena setiap spesies memiliki aktivitas biologi yang berbeda

Tujuan: Review ini ditujukan untuk mengetahui spesies kimia Selenium yang terdapat pada sayuran serta manfaat dan toksisitasnya bagi tubuh

Metode: Penelusuran referensi dilakukan melalui database Pubmed dan Google Scholar, dengan kata kunci "Selenium speciation in plant", "selenite", "selenate”, "selenomethionine”, "selenocystine”, dan "semethylselenocysteine

Hasil: Hasil spesiasi pada beberapa sayuran menunjukkan spesies kimia Selenium yang banyak terdapat dalam sayuran adalah selenomethionine (SeMet), selenocystine (SeCys $\mathrm{S}_{2}$ ), dan Se-methylselenocysteine (SeMeSeCys), $\gamma$-glutamyl-Se-methyl-selenocysteine, dan spesies anorganik. Baik sayuran yang diperkaya Selenium maupun spesies yang terkandung di dalamnya memiliki berbagai manfaat bagi tubuh. Namun konsumsi yang berlebih juga dapat menyebabkan efek toksik

Kesimpulan: Spesies kimia Selenium yang terdapat pada sayuran dapat berupa spesies organik maupun spesies anorganik. Kedua jenis spesies ini memiliki manfaat serta efek toksik yang berbeda

Kata kunci : manfaat, sayuran, Selenium, spesies kimia, toksisitas 


\section{Pendahuluan}

Selenium (Se) merupakan trace element esensial yang penting untuk berbagai fungsi biologi seperti metabolisme hormon tiroid, sistem pertahanan antioksidan tubuh, pencegah kanker tertentu dan sistem kardiovaskular (Benstoem et al., 2015). Selenium merupakan komponen penting dari enzim antioksidan seperti glutathione peroxidase (GPx) dan thioredoxin reductase (TrxR) serta selenoprotein $\mathrm{P}$ yang berfungsi dalam penyimpanan dan transportasi Selenium (Kielczykowska et al., 2018). Rekomendasi asupan Se tergantung dari usia serta kondisi dari setiap individu. Recommended Dietary Allowance (RDA) untuk pria dan wanita dewasa menurut Institute of Medicine (2000) adalah $55 \mu \mathrm{g} / \mathrm{hari}$. Kekurangan asupan Selenium yang parah dapat menyebabkan penyakit yang disebut Keshan dan Kashin-Beck (Stoffaneller \& Morse, 2015). Namun, kelebihan asupan Se juga dapat menyebabkan efek toksik bagi tubuh. Level tertinggi asupan Se yang kemungkinan tidak menimbulkan efek resiko bagi kesehatan adalah $400 \mu \mathrm{g} \mathrm{Se} /$ hari (Anonim, 2000). Makanan, salah satunya yaitu sayuran, merupakan sumber utama asupan Se (Thiry et al., 2013). Sayuran merupakan sumber antioksidan dan senyawa nutraseutikal yang penting bagi manusia (El-Ramady et al., 2014). Biofortifikasi Se pada makanan seperti pada sayuran dapat membantu mengatasi kekurangan asupan Se serta meningkatkan nilai nutrisi pada makanan (D'Amato et al., 2020).

Kandungan Se dalam tanaman sangat tergantung pada jumlah Se dalam tanah yang bervariasi disetiap daerah dan juga tergantung pada kemampuan tanaman untuk mengambil dan mengakumulasi Se (Thiry et al., 2013). Tanaman menggunakan S transporter dan jalur metabolik untuk mengambil Selenium anorganik (selenit dan selenat) yang terdapat di dalam tanah, kemudian diasimilasi menjadi Selenium organik selenocysteine (SeCys) dan selenomethionine (SeMet) yang selanjutnya dimetilasi dan disimpan dalam bentuk methyl-SeCys atau methyl-SeMet dan dikonversi menjadi senyawa volatil dimethylselenide (DMSe) atau dimethyldiselenide (DMDSe) (Schiavon \& Pilon-Smits, 2017).

Spesies kimia dari Selenium ini penting untuk diketahui karena setiap spesies kimia akan dimetabolisme dengan cara yang berbeda di dalam tubuh, sehingga akan memiliki aktivitas biologi yang berbeda pula (Weekley \& Harris, 2013). Toksisitas Selenium juga tergantung pada jenis spesies kimianya (Yang \& Jia, 2014). Maka dari itu, tujuan dari review ini adalah untuk mengetahui berbagai spesies Selenium yang terdapat pada sayuran serta manfaat dan toksisitasnya bagi tubuh.

\section{Metodologi penelitian}

Metode yang digunakan dalam review ini yaitu penelusuran pustaka dari berbagai jurnal internasional. Pencarian dilakukan pada database Pubmed dan Google Scholar, dengan kata kunci "Selenium speciation in plant", "selenite", "selenate", "selenomethionine", "selenocystine", dan 
"Se-methylselenocysteine". Artikel yang disitasi adalah artikel yang ditulis 10 tahun terakhir. Kriteria artikel yang digunakan berisi mengenai analisis identifikasi spesies kimia Selenium pada sampel sayuran, analisis aktivitas sayuran yang diperkaya Selenium, analisis aktivitas spesies Selenium yang dapat diterapkan pada manusia, serta analisis toksisitas spesies Selenium yang dapat diterapkan pada manusia.

\section{Hasil dan pembahasan}

\subsection{Kandungan dalam sayuran}

Tabel 1 menunjukkan hasil spesiasi Selenium pada berbagai jenis sayuran.Pada Tabel 1 dapat diketahui bahwa spesies Selenium organik yang umum terdapat pada sayuran adalah selenomethionine (SeMet), selenocystine ( $\left.\mathrm{SeCys}_{2}\right)$, dan Se-methylselenocysteine (Se-MeSeCys). Ada pula $\gamma$-Glutamyl-Se-methyl-selenocysteine yang terdapat pada beberapa sayuran terutama genus Allium. Jumlah spesies Selenium terbanyak pada setiap sayuran berbeda tergantung dari spesies tanamannya. Pada tanaman genus Brassica seperti brokoli (Brassica oleracea convar. italica) dan pakchoi (Brassica chinensis var parachinensis), Se-MeSeCys terdapat dalam jumlah yang lebih banyak daripada SeMet (Thosaikham et al., 2014). Sedangkan pada bawang perai (Allium ampeloprasum), SeMet lebih dominan dibandingkan Se-MeSeCys (Lavu et al., 2012).

Jumlah spesies Selenium anorganik, yaitu selenit (Se(IV)) dan selenat (Se(VI)) dipengaruhi oleh jenis Selenium yang ditambahkan sebelum dilakukan spesiasi. Pada penelitian yang dilakukan H. Zhang, et al. (2019), dilakukan dua cara fertilisasi pada kentang yang diperkaya Selenium yaitu dengan penambahan selenit dan selenat. Hasil spesiasi menunjukkan bahwa pada pemberian selenit, spesies selenit tidak terdeteksi dan jumlah Se organik sekitar 96,9-100\%. Sedangkan pada pemberian selenat, jumlah Se organik hanya sekitar 57,2\% dan sisanya merupakan selenat. Berdasarkan hasil tersebut didapatkan fertilisasi menggunakan selenit lebih baik daripada menggunakan selenat karena jumlah Se anorganik yang lebih sedikit.

Pada penanaman dengan menggunakan media tanah, selain jumlah Se anorganik yang lebih banyak, jumlah Se organik juga lebih banyak pada pemberian selenat daripada pemberian selenit. Hal ini dapat disebabkan karena selenit lebih sedikit tersedia di alam dibanding selenat dan lebih kuat diserap oleh besi oksida atau hidroksida, sedangkan selenat lebih larut dalam air. Selain itu, pengambilan selenat dalam tanah mengikuti jalur transporter sulfur, sedangkan selenit tidak tergantung pada proses metabolisme (Lavu et al., 2012).

Selain empat spesies organik yang umum terdapat pada sayuran, masih terdapat spesies Selenium lain yang tidak teridentifikasi pada saat spesiasi. Seperti pada spesiasi brokoli oleh Šindelářová, et al. (2015), hasil spesiasi menggunakan ICP-MS menunjukkan adanya 17 spesies yang berbeda, tetapi hanya 4 spesies yang teridentifikasi. Hal ini disebabkan karena tidak adanya standar dari spesies kimia tersebut. Maka, pada pengujian bawang putih yang dilakukan 
oleh Ruszczyńska, et al.(2017), digunakan HPLC-ESI-Orbitrap-MS/MS untuk mengetahui spesies Selenium yang tidak teridentifikasi. Dari hasil pengujian tersebut didapatkan spesies Selenium lainnya, yaitu selenohomolanthionine, selenomethionine oxide, deaminohydroxyselenohomolanthionine, $\mathrm{N}$-acetylcysteine-selenomethionine, methylseleno-Se-pentose-hexose, dan Se-methyl-selenoglutathione.

Tabel 1. Spesies Selenium pada sayuran

\begin{tabular}{|c|c|c|c|c|c|c|c|}
\hline \multirow[b]{2}{*}{ Nama tanaman } & \multicolumn{6}{|c|}{ Spesies Selenium } & \multirow[b]{2}{*}{ Pustaka } \\
\hline & $\operatorname{Se}(I V)$ & $\mathrm{Se}(\mathrm{VI})$ & SeMet & SeCys $_{2}$ & $\begin{array}{c}\text { Se- } \\
\text { MeSeCys }\end{array}$ & $\begin{array}{l}\gamma \text {-Glu-Se- } \\
\text { MeSeCys }\end{array}$ & \\
\hline $\begin{array}{l}\text { Brokoli } \\
\text { (Brassica oleracea } \\
\text { convar. italica) }\end{array}$ & - & + & + & + & + & - & $\begin{array}{l}\text { (Sindelarova et } \\
\text { al., 2015) }\end{array}$ \\
\hline $\begin{array}{l}\text { Pakchoi } \\
\text { (Brassica chinensis } \\
\text { var parachinensis) }\end{array}$ & - & + & + & - & + & - & $\begin{array}{l}\text { (Thosaikham et } \\
\text { al., 2014) }\end{array}$ \\
\hline $\begin{array}{l}\text { Kubis (Brassica } \\
\text { oleracea) }\end{array}$ & + & + & + & + & - & - & $\begin{array}{l}\text { (Funes-Collado } \\
\text { et al., 2015) }\end{array}$ \\
\hline $\begin{array}{l}\text { Selada } \\
\text { (Lactuca sativa L.) }\end{array}$ & + & + & + & + & - & - & $\begin{array}{l}\text { (do Nascimento } \\
\text { da Silva et al., } \\
\text { 2017) }\end{array}$ \\
\hline $\begin{array}{l}\text { Bawang putih } \\
\text { (Allium sativum L.) }\end{array}$ & + & - & + & - & + & + & $\begin{array}{l}\text { (Ruszczyńska et } \\
\text { al., 2017) }\end{array}$ \\
\hline $\begin{array}{l}\text { Bawang merah } \\
\text { (Allium cepa) }\end{array}$ & + & + & + & + & + & + & $\begin{array}{l}\text { (Kápolna et al., } \\
\text { 2012) }\end{array}$ \\
\hline $\begin{array}{l}\text { Bawang perai } \\
\text { (Allium } \\
\text { ampeloprasum) }\end{array}$ & + & + & + & + & + & + & $\begin{array}{l}\text { (Lavu et al., } \\
\text { 2012) }\end{array}$ \\
\hline $\begin{array}{l}\text { Kentang } \\
\text { (Solanum } \\
\text { tuberosum L.) }\end{array}$ & + & + & + & + & + & - & $\begin{array}{l}\text { (H. Zhang et al., } \\
\text { 2019) }\end{array}$ \\
\hline $\begin{array}{l}\text { Wortel } \\
\text { (Daucus carota) }\end{array}$ & + & + & + & + & + & + & $\begin{array}{l}\text { (Bañuelos et al., } \\
\text { 2016; Kápolna } \\
\text { et al., 2012) }\end{array}$ \\
\hline $\begin{array}{l}\text { Jagung } \\
\text { (Zea mays L.) }\end{array}$ & - & - & + & + & + & - & $\begin{array}{l}\text { (Z. Zhang et al., } \\
\text { 2019) }\end{array}$ \\
\hline $\begin{array}{l}\text { Keterangan: } \\
(+) \text { mengandung spes } \\
\text { Singkatan: }\end{array}$ & Seleniuı & +4 & s & +2 & ium & & \\
\hline
\end{tabular}

Dari berbagai jenis sayuran yang diteliti, sayuran dari genus Brassica dan Allium memiliki kemampuan yang baik dalam akumulasi Se karena tumbuhan ini mengandung lebih banyak fraksi asam amino yang mengandung sulfur serta mengandung senyawa sulfur lainnya seperti glikosinolat atau sulfoksida. Brokoli dan bawang putih juga dapat mengakumulasi Se tanpa menimbulkan perubahan pada pertumbuhan tanaman serta tidak mengubah jumlah dari cysteine, glutathione, total glukosinolat serta senyawa lain. Hal ini menunjukkan kedua sayuran ini memiliki kemampuan yang lebih besar untuk digunakan dalam biofortifikasi Se (Hsu et al., 2011; Pérez et al., 2019). 


\subsection{Manfaat spesies Selenium yang terkandung dalam sayuran}

Biofortifikasi Se pada sayuran dapat digunakan sebagai alternatif suplementasi Se (Amato et al., 2017). Selain itu, didapatkan juga manfaat lain seperti pada penelitian yang dilakukan Põldma, penambahan Selenium sebanyak 10-50 $\mu \mathrm{g}$ Se/mL dapat meningkatkan kapasitas antioksidan pada bawang putih (Poldma et al., 2011). Hal tersebut juga terjadi pada bawang merah (Põldma et al., 2013). Bawang putih yang diperkaya Selenium juga terbukti dapat memberi efek penghambatan sel kanker payudara yang lebih besar dari pada bawang putih alami (Tsubura et al., 2011). Pada penelitian juga dibuktikan bahwa mengonsumsi brokoli yang diperkaya oleh Se dapat meningkatkan respon imun terhadap berbagai tantangan sistem imun (Bentley-Hewitt et al., 2014). Terdapat juga penelitian yang menunjukkan bahwa makanan yang diperkaya Selenium dapat meningkatkan aktivitas glutathione proxidase (GPx), salah satu enzim antioksidan, yang lebih baik dibandingkan dengan bentuk Selenium lain (Bermingham et al., 2014).

Tabel 2. Manfaat spesies Selenium

\begin{tabular}{|c|c|c|c|}
\hline Spesies Selenium & Kegunaan & Mekanisme & Pustaka \\
\hline \multirow[t]{4}{*}{ Selenit } & $\begin{array}{l}\text { Antikanker } \\
\text { prostat }\end{array}$ & $\begin{array}{l}\text { Pemberian kombinasi dengan docetaxel } \\
\text { memberikan efek sinergis terhadap } \\
\text { penghambatan pertumbuhan sel dan secara } \\
\text { signifikan menginduksi kematian sel }\end{array}$ & $\begin{array}{l}\text { (Freitas et al., } \\
\text { 2011) }\end{array}$ \\
\hline & $\begin{array}{l}\text { Antikanker paru- } \\
\text { paru }\end{array}$ & $\begin{array}{l}\text { Menginduksi apoptosis dan autofagi yang } \\
\text { dimediasi oleh generasi ROS }\end{array}$ & $\begin{array}{l}\text { (Park et al., } \\
\text { 2012) }\end{array}$ \\
\hline & $\begin{array}{l}\text { Antikanker } \\
\text { tulang }\end{array}$ & $\begin{array}{l}\text { Menginduksi apoptosis sel yang dimediasi } \\
\text { oleh generasi ROS }\end{array}$ & $\begin{array}{l}\text { (Chen et al., } \\
\text { 2012) }\end{array}$ \\
\hline & $\begin{array}{l}\text { Antikanker } \\
\text { mulut }\end{array}$ & $\begin{array}{l}\text { Menghambat pertumbuhan sel dan } \\
\text { menginduksi apoptosis sel }\end{array}$ & $\begin{array}{l}\text { (Endo et al., } \\
\text { 2017) }\end{array}$ \\
\hline \multirow[t]{4}{*}{ Selenat } & $\begin{array}{l}\text { Antikanker } \\
\text { prostat }\end{array}$ & $\begin{array}{l}\text { Menghambat perkembangan tumor pada } \\
\text { mencit dewasa }\end{array}$ & $\begin{array}{l}\text { (Holmstrom et } \\
\text { al., 2012) }\end{array}$ \\
\hline & $\begin{array}{l}\text { Antikanker paru- } \\
\text { paru }\end{array}$ & $\begin{array}{l}\text { Chitosan selenat (CS) menginduksi } \\
\text { apoptosis sel melalui jalur Fas/FasL }\end{array}$ & $\begin{array}{l}\text { (Gao et al., } \\
\text { 2020) }\end{array}$ \\
\hline & $\begin{array}{l}\text { Proteksi } \\
\text { terhadap efek } \\
\text { teratogenik }\end{array}$ & $\begin{array}{l}\text { Melindungi janin beserta plasentanya dari } \\
\text { efek teratogenik cisplatin }\end{array}$ & $\begin{array}{l}\text { (Hassan et al., } \\
\text { 2016) }\end{array}$ \\
\hline & Anti-epilepsi & $\begin{array}{l}\text { Mengurangi fosforilasi protein tau sehingga } \\
\text { dapat mengurangi durasi kejang }\end{array}$ & $\begin{array}{l}\text { (Jones et al., } \\
\text { 2012) }\end{array}$ \\
\hline \multirow[t]{4}{*}{$\begin{array}{l}\text { Selenomethionine } \\
\text { (SeMet) }\end{array}$} & $\begin{array}{l}\text { Antikanker } \\
\text { payudara }\end{array}$ & $\begin{array}{l}\text { Pembentukan kompleks dengan platinum } \\
\text { menghasilkan aktivitas antikanker yang } \\
\text { lebih tinggi dan efek samping yang lebih } \\
\text { kecil dibandingkan cisplatin dengan cara } \\
\text { mengonsumsi glutathione (GSH) sehingga } \\
\text { konsentrasi ROS meningkat dan } \\
\text { menghasilkan apoptosis sel }\end{array}$ & (Li et al., 2018) \\
\hline & $\begin{array}{l}\text { Pencegahan } \\
\text { kanker } \\
\text { kolorektal }\end{array}$ & $\begin{array}{l}\text { Mencegah kanker kolorektal dengan } \\
\text { memodulasi ekspresi } 30 \text { protein yang } \\
\text { memiliki fungsi utama pada inflamasi } \\
\text { kronik, stres oksidatif dan apoptosis }\end{array}$ & $\begin{array}{l}\text { (Rahman \& Seo, } \\
\text { 2013) }\end{array}$ \\
\hline & $\begin{array}{l}\text { Pencegahan } \\
\text { kanker kulit }\end{array}$ & $\begin{array}{l}\text { Mencegah kanker kulit yang diinduksi UV-B } \\
\text { dengan pemberian topikal sebelum, selama, } \\
\text { dan setelah paparan radiasi }\end{array}$ & $\begin{array}{l}\text { (Burke et al., } \\
\text { 2014) }\end{array}$ \\
\hline & Autoimun & Meningkatkan efek vitamin $\mathrm{D}$ pada tiroid & (Krysiak et al., \\
\hline
\end{tabular}




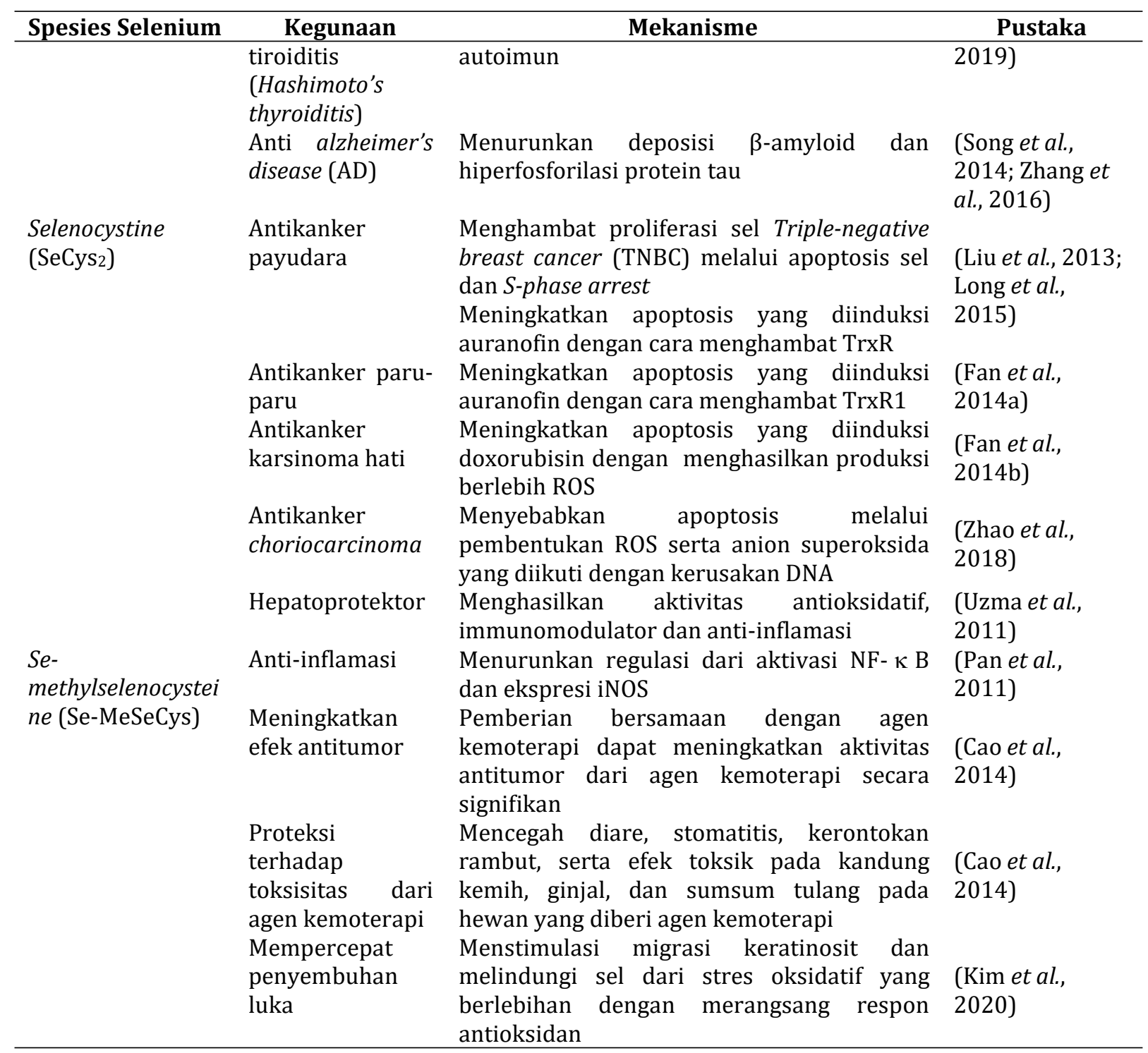

Pengujian spesies Selenium baik secara in vitro maupun in vivo pada hewan uji juga menunjukkan adanya berbagai macam aktivitas biologis seperti yang terdapat pada Tabel 2 . Banyak penelitian menunjukkan bahwa spesies Selenium memiliki aktivitas antikanker. Aktivitas antikanker ini kebanyakan dipengaruhi oleh produksi reactive oxygen species (ROS). ROS secara dinamis dapat mempengaruhi lingkungan mikro dari sel tumor dan diketahui dapat memicu angiogenesis kanker, metastasis, dan kelangsungan hidup sel pada konsentrasi yang berbeda. Pada konsentrasi sedang, ROS mengaktifkan kaskade pensinyalan kelangsungan hidup sel kanker. Pada konsentrasi tinggi, ROS dapat menyebabkan apoptosis sel kanker (Aggarwal et al., 2019). Spesies Selenium dapat meningkatkan produksi ROS sehingga menyebabkan apoptosis sel. Spesies Selenium yang dikombinasikan dengan obat antikanker juga memiliki efek sinergis, sehingga aktivitas antikanker dapat meningkat. Seperti pada penelitian SeCys yang dilakukan terhadap sel kanker payudara dan paru-paru, menujukkan bahwa SeCys 2 dapat mensinergikan apoptosis yang diinduksi oleh auranofin dengan menghambat aktivitas 
thioredoxin reductase (TrxR), sehingga meningkatkan akumulasi ROS yang menyebabkan kerusakan DNA dan inaktivasi ERK dan AKT (Fan et al., 2014a; Liu et al., 2013). Namun, pada hasil pengujian secara klinik spesies Selenium terhadap kanker prostat dan paru-paru menunjukkan hasil bahwa pemberian Selenium tidak memiliki perbedaan dengan pemberian plasebo (Algotar et al., 2013; Karp et al., 2013).

Selain sebagai antikanker, spesies Selenium organik juga memiliki berbagai manfaat lain. Seperti pada pengujian selenat dan SeMet yang menunjukkan bahwa keduanya dapat menurunkan fosforilasi protein tau sehingga dapat digunakan sebagai anti-epilepsi untuk selenat dan anti alzheimer's disease (AD) untuk SeMet (Jones et al., 2012; Song et al., 2014). Pada pemberian SeCys 2 sebelum menginduksi kerusakan hati dengan $\mathrm{CCl}_{4}$ pada hewan uji, menunjukkan hasil secara signifikan bahwa SeCys 2 dapat mencegah pembentukan ROS, malondialdehyde (MDA), penipisan glutathione, dan perubahan aktivitas enzim antioksidan, sehingga menunjukkan adanya efek hepatoprotektif (Uzma et al., 2011). Pada pemberian SeMeSeCys secara oral pada hewan yang diberi agen kemoterapi, spesies ini dapat memberikan perlindungan selektif terhadap toksisitas spesifik organ yang diinduksi oleh agen kemoterapi dan meningkatkan aktivitas antitumor, sehingga meningkatkan indeks terapeutik (Cao et al., 2014). Pada penelitian lain juga didapatkan bahwa Se-MeSeCys dapat menghambat produksi NO yang diinduksi lipopolisakarida dengan penurunan ekspresi gen dan kadar protein inducible nitric oxide synthase (iNOS) serta mengurangi translokasi subunit p65 dan p50 dari nuclear

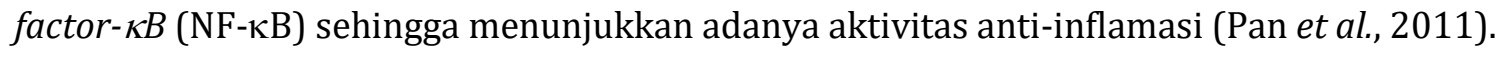

\subsection{Toksisitas spesies Selenium pada sayuran}

Pada penelitian yang dilakukan oleh MacFarquhar, et al. (2010), kasus toksisitas Selenium karena asupan suplemen Selenium yang berlebihan selama dua minggu dapat menimbulkan beberapa gejala seperti diare, kelelahan, rambut rontok, nyeri sendi, perubahan warna kuku atau kerapuhan, dan mual (MacFarquhar et al., 2010). Toksisitas kronis Selenium dapat menyebabkan kondisi yang disebut selenosis, yang ditandai dengan kerontokan dan kerapuhan dari rambut dan kuku, masalah pencernaan, ruam kulit, bau bawang putih pada napas, dan kelainan sistem saraf. Di Cina dilaporkan bahwa selenosis terjadi pada orang yang mengkonsumsi Selenium diatas $910 \mu \mathrm{g} /$ hari. Maka dari itu Institute of Medicine (2000) menetapkan bahwa level tertinggi asupan Se yang kemungkinan tidak menimbulkan efek resiko bagi kesehatan adalah pada $400 \mu \mathrm{g}$ Se/hari, dihitung dari $800 \mu \mathrm{g}$ dibagi dengan uncertainty factor (UF) yang memiliki nilai dua untuk melindungi individu yang sensitif.

Toksisitas pada sayuran yang diperkaya Se dapat dilihat dari hasil perhitungan kandungan Se di dalamnya. Seperti pada brokoli yang diperkaya Se yang memiliki jumlah Se maksimum sekitar $1,01 \mathrm{mg} / \mathrm{kg}$, tidak akan menimbulkan resiko toksisitas dengan dasar perhitungan bahwa pada $1 \mathrm{~kg}$ brokoli mengandung rata-rata $18 \%$ jumlah kering, sehingga $1 \mathrm{~kg}$ 
brokoli mengandung $180 \mu \mathrm{g}$ Se. Jumlah ini aman untuk dikonsumsi dan dapat digunakan untuk alternatif suplementasi Se (Sindelarova et al., 2015). Pada perhitungan kandungan Se pada kentang dengan konsumsi per hari per orang adalah 0,3 $\mathrm{kg}$, maka jumlah Se pada kentang dengan biofortifikasi menggunakan selenit adalah sebesar 78,8 $\mu \mathrm{g} / \mathrm{hari}$. Jumlah ini dapat dikatakan aman untuk dikonsumsi dan dapat juga dikonsumsi bersamaan dengan asupan Se dari makanan lain (H. Zhang et al., 2019).

Toksisitas Selenium juga tergantung pada jenis spesies kimianya. Unsur Selenium dan logam selenida memiliki toksisitas yang relatif lebih sedikit karena bioavailabilitas yang lebih rendah. Sedangkan, spesies organik dan anorganik yang banyak digunakan sebagai sumber nutrisi dapat menyebabkan efek toksik pada jumlah yang besar. SeMet memiliki toksisitas yang lebih kecil dibandingkan spesies Selenium anorganik (Yang \& Jia, 2014). Se-MeSeCys juga dilaporkan memiliki toksisitas yang lebih kecil dan lebih bioaktif daripada Selenium anorganik dan Selenium organik lainnya (Hoefig et al., 2011).

Pada penelitian yang dilakukan terhadap zebrafish (Danio rerio) yang ditujukan untuk melihat efek terhadap perkembangan embrio, menunjukkan pemberian selenit dengan konsentrasi tinggi $(\geq 10 \mu \mathrm{M})$ dapat menyebabkan perkembangan embrio yang tertunda, penurunan tingkat penetasan, mortilitas, dan malformasi. Selain itu, paparan selenit juga menyebabkan kerusakan kardiovaskular dan saraf pada embrio. Suplementasi asam folat dapat melindungi dari embriotoksisitas ini (Ma et al., 2012). Pada pengujian toksikokinetik dosis oral dari spesies Selenium menunjukkan bahwa MeSeCys lebih cepat diserap daripada SeMet pada dosis yang sama, sedangkan natrium selenat diserap pada tingkat yang sama dengan SeMet dan diserap lebih baik daripada natrium selenit dalam serum dan darah. Urutan AUC atau bioavailabilitas pada darah dan serum adalah selenit $<$ SeMet $<$ selenat $<$ MeSeCys (Davis et al., 2013; Davis et al., 2017).

\section{Kesimpulan}

Spesies organik Selenium yang paling banyak terdapat pada sayuran adalah selenomethionine (SeMet), selenocystine ( $\mathrm{SeCys}_{2}$ ), Se-methylselenocysteine (Se-MeSeCys), serta $\gamma$ Glutamyl-Se-methyl-selenocysteine. Jumlahnya berbeda tergantung dari spesies tanamannya. Jumlah spesies Selenium anorganik (selenit dan selenat) dipengaruhi oleh jenis Selenium yang ditambahkan sebelum dilakukan spesiasi. Selain spesies tersebut, masih terdapat spesies Selenium lain yang belum diketahui karena tidak tersedianya standar, namun sudah terdapat penelitian yang menggunakan tandem MS untuk mendeteksi spesies yang tidak diketahui. Baik sayuran yang diperkaya Selenium maupun spesies yang terkandung di dalamnya memiliki berbagai manfaat seperti aktivitas antikanker, anti alzheimer's disease (AD), hepatoprotektor, anti-inflamasi, dan manfaat lainnya. Namun, konsumsi yang berlebih juga dapat menyebabkan 
efek toksik bagi tubuh. Level tertinggi asupan Se yang kemungkinan tidak menimbulkan efek resiko bagi kesehatan adalah $400 \mu \mathrm{g} \mathrm{Se/hari.}$

\section{Ucapan terimakasih}

Terimakasih kepada KEMENRISTEK DIKTI atas hibah yang telah diberikan dengan nomor grant 1123ah/UN6.0/LT/2019 untuk penulisan review artikel ini.

\section{Daftar pustaka}

Aggarwal, V., Tuli, H. S., Varol, A., Thakral, F., Yerer, M. B., Sak, K., Varol, M., Jain, A., Khan, M. A., \& Sethi, G. (2019). Role of reactive oxygen species in cancer progression: molecular mechanisms and recent advancements. Biomolecules, 9(11), 735. doi:10.3390/biom9110735

Algotar, A. M., Stratton, M. S., Ahmann, F. R., Ranger-Moore, J., Nagle, R. B., Thompson, P. A., Slate, E., Hsu, C. H., Dalkin, B. L., Sindhwani, P., Holmes, M. A., Tuckey, J. A., Graham, D. L., Parnes, H. L., Clark, L. C., \& Stratton, S. P. (2013). Phase 3 clinical trial investigating the effect of Selenium supplementation in men at high-risk for prostate cancer. The Prostate, 73(3), 328-335. doi:10.1002/pros.22573

Amato, R., Lim, P., Miotto, O., Amaratunga, C., Dek, D., Pearson, R. D., Almagro-Garcia, J., Neal, A. T., Sreng, S., Suon, S., Drury, E., Jyothi, D., Stalker, J., Kwiatkowski, D. P., \& Fairhurst, R. M. (2017). Genetic markers associated with dihydroartemisinin-piperaquine failure in Plasmodium falciparum malaria in Cambodia: a genotype-phenotype association study. Lancet Infect Dis, 17(2), 164-173. doi:10.1016/S1473-3099(16)30409-1

Anonim. (2000). Dietary reference intakes for vitamin C, vitamin E, Selenium, and carotenoids. Washington (DC): Institute of Medicine (US) Panel on Dietary Antioxidants and Related Compounds, National Academies Press (US).

Bañuelos, G. S., Arroyo, I. S., Dangi, S. R., \& Zambrano, M. C. (2016). Continued Selenium biofortification of carrots and broccoli grown in soils once amended with Se-enriched S. pinnata. Front Plant Sci, 7, 1251. doi:10.3389/fpls.2016.01251

Benstoem, C., Goetzenich, A., Kraemer, S., Borosch, S., Manzanares, W., Hardy, G., \& Stoppe, C. (2015). Selenium and its supplementation in cardiovascular disease--what do we know? Nutrients, 7(5), 30943118. doi:10.3390/nu7053094

Bentley-Hewitt, K., Chen, R., Lill, R., Hedderley, D., Herath, T., Matich, A., \& McKenzie, M. (2014). Consumption of Selenium-enriched broccoli increases cytokine production in human peripheral blood mononuclear cells stimulated ex vivo, a preliminary human intervention study. Molecular Nutrition \& Food Research, 58. doi:10.1002/mnfr.201400438

Bermingham, E. N., Hesketh, J. E., Sinclair, B. R., Koolaard, J. P., \& Roy, N. C. (2014). Selenium-enriched foods are more effective at increasing glutathione peroxidase (GPx) activity compared with selenomethionine: a meta-analysis. Nutrients, 6(10), 4002-4031. doi:10.3390/nu6104002

Burke, K. E., Zhou, X., Wang, Y., Commisso, J., Keen, C. L., Nakamura, R. M., Combs, G. F., Jr., \& Wei, H. (2014). The effects of topical L-selenomethionine on protection against UVB-induced skin cancer when given before, during, and after UVB exposure. J Drugs Dermatol, 13(10), 1214-1223.

Cao, S., Durrani, F. A., Tóth, K., \& Rustum, Y. M. (2014). Se-methylselenocysteine offers selective protection against toxicity and potentiates the antitumour activity of anticancer drugs in preclinical animal models. Br J Cancer, 110(7), 1733-1743. doi:10.1038/bjc.2014.85

Chen, X. J., Duan, F. D., Zhang, H. H., Xiong, Y., \& Wang, J. (2012). Sodium selenite-induced apoptosis mediated by ROS attack in human osteosarcoma U2OS cells. Biol Trace Elem Res, 145(1), 1-9. doi:10.1007/s12011-011-9154-2

D'Amato, R., Regni, L., Falcinelli, B., Mattioli, S., Benincasa, P., Dal Bosco, A., Pacheco, P., Proietti, P., Troni, E., Santi, C., \& Businelli, D. (2020). Current knowledge on Selenium biofortification to improve the nutraceutical profile of food: a comprehensive review. J Agric Food Chem, 68(14), 4075-4097. doi:10.1021/acs.jafc.0c00172

Davis, T. Z., Stegelmeier, B. L., Welch, K. D., Pfister, J. A., Panter, K. E., \& Hall, J. O. (2013). Comparative oral dose toxicokinetics of Selenium compounds commonly found in Selenium accumulator plants. J Anim Sci, 91(9), 4501-4509. doi:10.2527/jas.2012-6101 
Davis, T. Z., Tiwary, A. K., Stegelmeier, B. L., Pfister, J. A., Panter, K. E., \& Hall, J. O. (2017). Comparative oral dose toxicokinetics of sodium selenite and selenomethionine. J Appl Toxicol, 37(2), 231-238. doi:10.1002/jat.3350

do Nascimento da Silva, E., Aureli, F., D'Amato, M., Raggi, A., Cadore, S., \& Cubadda, F. (2017). Selenium bioaccessibility and speciation in Selenium-enriched lettuce: investigation of the Selenocompounds liberated after in vitro simulated human digestion using two-dimensional HPLC-ICP-MS. J Agric Food Chem, 65(14), 3031-3038. doi:10.1021/acs.jafc.7b01188

El-Ramady, H., Abdalla, N., Fári, M., \& domokos-szabolcsy, E. (2014). Selenium enriched vegetables as biofortification alternative for alleviating micronutrient malnutrition. International Journal of Horticultural Science, 20, 75 - 81. doi:10.31421/IJHS/20/1-2/1121

Endo, M., Hasegawa, H., Kaneko, T., Kanno, C., Monma, T., Kano, M., Shinohara, F., \& Takahashi, T. (2017). Antitumor activity of Selenium compounds and its underlying mechanism in human oral squamous cell carcinoma cells: a preliminary study. Journal of Oral and Maxillofacial Surgery, Medicine, and Pathology, 29(1), 17-23. doi:https://doi.org/10.1016/j.ajoms.2016.08.006

Fan, C., Zheng, W., Fu, X., Li, X., Wong, Y. S., \& Chen, T. (2014a). Enhancement of auranofin-induced lung cancer cell apoptosis by selenocystine, a natural inhibitor of TrxR1 in vitro and in vivo. Cell death \& disease, 5(4), e1191-e1191. doi:10.1038/cddis.2014.132

Fan, C., Zheng, W., Fu, X., Li, X., Wong, Y. S., \& Chen, T. (2014b). Strategy to enhance the therapeutic effect of doxorubicin in human hepatocellular carcinoma by selenocystine, a synergistic agent that regulates the ROS-mediated signaling. Oncotarget, 5(9), 2853-2863. doi:10.18632/oncotarget.1854

Freitas, M., Alves, V., Sarmento-Ribeiro, A., \& Mota Pinto, A. (2011). Combined effect of sodium selenite and docetaxel on PC3 metastatic prostate cancer cell line. Biochemical and biophysical research communications, 408, 713-719. doi:10.1016/j.bbrc.2011.04.109

Funes-Collado, V., Rubio, R., \& López-Sánchez, J. F. (2015). Does boiling affect the bioaccessibility of Selenium from cabbage? Food Chemistry, 304-309. doi:https://doi.org/10.1016/j.foodchem.2015.02.052

Gao, J., Zhao, Y., Wang, C., Ji, H., Yu, J., Liu, C., \& Liu, A. (2020). A novel synthetic chitosan selenate (CS) induces apoptosis in A549 lung cancer cells via the Fas/FasL pathway. International Journal of Biological Macromolecules, 158, 689-697. doi:https://doi.org/10.1016/i.ijbiomac.2020.05.016

Hassan, M., Morgan, A., Mekawy, M., Zaki, A., \& Ghazi, Z. (2016). Teratogenic effect of cisplatin in rats and the protective role of sodium selenate. Experimental and Toxicologic Pathology, 68. doi:10.1016/j.etp.2016.02.003

Hoefig, C. S., Renko, K., Köhrle, J., Birringer, M., \& Schomburg, L. (2011). Comparison of different selenocompounds with respect to nutritional value vs. toxicity using liver cells in culture. $J$ Nutr Biochem, 22(10), 945-955. doi:10.1016/j.jnutbio.2010.08.006

Holmstrom, A., Wu, R. T. Y., Zeng, H., Lei, K. Y., \& Cheng, W.-H. (2012). Nutritional and supranutritional levels of selenate differentially suppress prostate tumor growth in adult but not young nude mice. The $\begin{array}{lllll}\text { Journal of Nutritional } & \text { Biochemistry, } & \text { 23(9), } & \text { 1086-1091. }\end{array}$ doi:https://doi.org/10.1016/j.jnutbio.2011.06.001

Hsu, F. C., Wirtz, M., Heppel, S. C., Bogs, J., Krämer, U., Khan, M. S., Bub, A., Hell, R., \& Rausch, T. (2011). Generation of Se-fortified broccoli as functional food: impact of Se fertilization on S metabolism. Plant Cell Environ, 34(2), 192-207. doi:10.1111/j.1365-3040.2010.02235.x

Jones, N. C., Nguyen, T., Corcoran, N. M., Velakoulis, D., Chen, T., Grundy, R., O'Brien, T. J., \& Hovens, C. M. (2012). Targeting hyperphosphorylated tau with sodium selenate suppresses seizures in rodent models. Neurobiol Dis, 45(3), 897-901. doi:10.1016/j.nbd.2011.12.005

Kápolna, E., Laursen, K. H., Husted, S., \& Larsen, E. H. (2012). Bio-fortification and isotopic labelling of Se metabolites in onions and carrots following foliar application of Se and 77Se. Food Chemistry, 133(3), 650-657. doi:https://doi.org/10.1016/j.foodchem.2012.01.043

Karp, D. D., Lee, S. J., Keller, S. M., Wright, G. S., Aisner, S., Belinsky, S. A., Johnson, D. H., Johnston, M. R., Goodman, G., Clamon, G., Okawara, G., Marks, R., Frechette, E., McCaskill-Stevens, W., Lippman, S. M., Ruckdeschel, J., \& Khuri, F. R. (2013). Randomized, double-blind, placebo-controlled, phase III chemoprevention trial of Selenium supplementation in patients with resected stage I non-small-cell lung cancer: ECOG 5597. J Clin Oncol, 31(33), 4179-4187. doi:10.1200/jco.2013.49.2173

Kielczykowska, M., Kocot, J., Pazdzior, M., \& Musik, I. (2018). Selenium - a fascinating antioxidant of protective properties. Adv Clin Exp Med, 27(2), 245-255. doi:10.17219/acem/67222

Kim, D., Ku, B., \& Choi, E. M. (2020). Se-methylselenocysteine stimulates migration and antioxidant response in HaCaT keratinocytes: Implications for wound healing. J Trace Elem Med Biol, 58, 126426. doi:10.1016/j.jtemb.2019.126426 
Krysiak, R., Kowalcze, K., \& Okopien, B. (2019). Selenomethionine potentiates the impact of vitamin D on thyroid autoimmunity in euthyroid women with Hashimoto's thyroiditis and low vitamin D status. Pharmacol Rep, 71(2), 367-373. doi:10.1016/j.pharep.2018.12.006

Lavu, R. V., Du Laing, G., Van de Wiele, T., Pratti, V. L., Willekens, K., Vandecasteele, B., \& Tack, F. (2012). Fertilizing soil with Selenium fertilizers: impact on concentration, speciation, and bioaccessibility of Selenium in leek (Allium ampeloprasum). J Agric Food Chem, 60(44), 10930-10935. doi:10.1021/jf302931z

Li, T., Xiang, W., Li, F., \& Xu, H. (2018). Self-assembly regulated anticancer activity of platinum coordinated selenomethionine. Biomaterials, 157, 17-25. doi:10.1016/j.biomaterials.2017.12.001

Liu, C., Liu, Z., Li, M., Li, X., Wong, Y. S., Ngai, S. M., Zheng, W., Zhang, Y., \& Chen, T. (2013). Enhancement of auranofin-induced apoptosis in MCF-7 human breast cells by selenocystine, a synergistic inhibitor of thioredoxin reductase. PLoS One, 8(1), e53945. doi:10.1371/journal.pone.0053945

Long, M., Wu, J., Hao, J., Liu, W., Tang, Y., Li, X., Su, H., \& Qiu, W. (2015). Selenocystine-induced cell apoptosis and S-phase arrest inhibit human triple-negative breast cancer cell proliferation. In Vitro Cell Dev Biol Anim, 51(10), 1077-1084. doi:10.1007/s11626-015-9937-4

Ma, Y., Wu, M., Li, D., Li, X. Q., Li, P., Zhao, J., Luo, M. N., Guo, C. L., Gao, X. B., Lu, C. L., \& Ma, X. (2012). Embryonic developmental toxicity of selenite in zebrafish (Danio rerio) and prevention with folic acid. Food Chem Toxicol, 50(8), 2854-2863. doi:10.1016/j.fct.2012.04.037

MacFarquhar, J. K., Broussard, D. L., Melstrom, P., Hutchinson, R., Wolkin, A., Martin, C., Burk, R. F., Dunn, J. R., Green, A. L., Hammond, R., Schaffner, W., \& Jones, T. F. (2010). Acute Selenium toxicity associated with a dietary supplement. Arch Intern Med, 170(3), 256-261. doi:10.1001/archinternmed.2009.495

Pan, M. H., Hong, H. M., Lin, C. L., Jhang, A. Z., Tsai, J. H., Badmaev, V., Nagabhushanam, K., Ho, C. T., \& Chen, W. J. (2011). Se-methylselenocysteine inhibits lipopolysaccharide-induced NF-kappaB activation and iNOS induction in RAW 264.7 murine macrophages. Mol Nutr Food Res, 55(5), 723-732. doi:10.1002/mnfr.201000481

Park, S. H., Kim, J. H., Chi, G. Y., Kim, G. Y., Chang, Y. C., Moon, S. K., Nam, S. W., Kim, W. J., Yoo, Y. H., \& Choi, Y. H. (2012). Induction of apoptosis and autophagy by sodium selenite in A549 human lung carcinoma cells through generation of reactive oxygen species. Toxicol Lett, 212(3), 252-261. doi:10.1016/j.toxlet.2012.06.007

Pérez, B., Lipinski, V., Filippini, M., Chacón-Madrid, K., Arruda, M., \& Wuilloud, R. (2019). Selenium biofortification on garlic growth and other nutrients accumulation. Horticultura Brasileira, 37, 294-301. doi:10.1590/s0102-053620190307

Põldma, P., Moor, U., Tõnutare, T., Herodes, K., \& Rebane, R. (2013). Selenium treatment under field conditions affects mineral nutrition, yield and antioxidant properties of bulb onion (Allium cepa L.). Acta scientiarum Polonorum. Hortorum cultus = Ogrodnictwo, 12, 167-181.

Poldma, P., Tonutare, T., Viitak, A., Luik, A., \& Moor, U. (2011). Effect of Selenium treatment on mineral nutrition, bulb size, and antioxidant properties of garlic (Allium sativum L.). J Agric Food Chem, 59(10), 5498-5503. doi:10.1021/jf200226p

Rahman, M. M., \& Seo, Y. R. (2013). Discovery of potential targets of selenomethionine-mediated chemoprevention in colorectal carcinoma mouse model using proteomics analysis. Carcinogenesis, 34(7), 1575-1584. doi:10.1093/carcin/bgt078

Ruszczyńska, A., Konopka, A., Kurek, E., Torres Elguera, J. C., \& Bulska, E. (2017). Investigation of biotransformation of Selenium in plants using spectrometric methods. Spectrochimica Acta Part B: Atomic Spectroscopy, 130, 7-16. doi:https://doi.org/10.1016/j.sab.2017.02.004

Schiavon, M., \& Pilon-Smits, E. A. (2017). Selenium biofortification and phytoremediation phytotechnologies: a review. J Environ Qual, 46(1), 10-19. doi:10.2134/jeq2016.09.0342

Sindelarova, K., Szakova, J., Tremlova, J., Mestek, O., Praus, L., Kana, A., Najmanova, J., \& Tlustos, P. (2015). The response of broccoli (Brassica oleracea convar. italica) varieties on foliar application of Selenium: uptake, translocation, and speciation. Food Addit Contam Part A Chem Anal Control Expo Risk Assess, 32(12), 2027-2038. doi:10.1080/19440049.2015.1099744

Song, G., Zhang, Z., Wen, L., Chen, C., Shi, Q., Zhang, Y., Ni, J., \& Liu, Q. (2014). Selenomethionine ameliorates cognitive decline, reduces tau hyperphosphorylation, and reverses synaptic deficit in the triple transgenic mouse model of Alzheimer's disease. J Alzheimers Dis, 41(1), 85-99. doi:10.3233/JAD131805

Stoffaneller, R., \& Morse, N. L. (2015). A review of dietary Selenium intake and Selenium status in Europe and the Middle East. Nutrients, 7(3), 1494-1537. doi:10.3390/nu7031494

Thiry, C., Schneider, Y. J., Pussemier, L., De Temmerman, L., \& Ruttens, A. (2013). Selenium bioaccessibility and bioavailability in Se-enriched food supplements. Biol Trace Elem Res, 152(1), 152-160. doi:10.1007/s12011-013-9604-0 
Thosaikham, W., Jitmanee, K., Sittipout, R., Maneetong, S., Chantiratikul, A., \& Chantiratikul, P. (2014). Evaluation of Selenium species in Selenium-enriched pakchoi (Brassica chinensis Jusl var parachinensis (Bailey) Tsen \& Lee) using mixed ion-pair reversed phase HPLC-ICP-MS. Food Chem, 145, 736-742. doi:10.1016/j.foodchem.2013.08.116

Tsubura, A., Lai, Y. C., Kuwata, M., Uehara, N., \& Yoshizawa, K. (2011). Anticancer effects of garlic and garlic-derived compounds for breast cancer control. Anticancer Agents Med Chem, 11(3), 249-253. doi:10.2174/187152011795347441

Uzma, N., Kumar, B. S., \& Priyadarsini, K. I. (2011). Hepatoprotective, immunomodulatory, and antiinflammatory activities of selenocystine in experimental liver injury of rats. Biol Trace Elem Res, 142(3), 723-734. doi:10.1007/s12011-010-8807-x

Weekley, C. M., \& Harris, H. H. (2013). Which form is that? The importance of Selenium speciation and metabolism in the prevention and treatment of disease. Chem Soc Rev, 42(23), 8870-8894. doi:10.1039/c3cs60272a

Yang, H., \& Jia, X. (2014). Safety evaluation of Se-methylselenocysteine as nutritional Selenium supplement: acute toxicity, genotoxicity and subchronic toxicity. Regul Toxicol Pharmacol, 70(3), 720-727. doi:10.1016/j.yrtph.2014.10.014

Zhang, H., Zhao, Z., Zhang, X., Zhang, W., Huang, L., Zhang, Z., Yuan, L., \& Liu, X. (2019). Effects of foliar application of selenate and selenite at different growth stages on Selenium accumulation and speciation in potato (Solanum tuberosum L.). Food Chemistry, 286, 550-556. doi:https://doi.org/10.1016/i.foodchem.2019.01.185

Zhang, Z., Yuan, L., Qi, S., \& Yin, X. (2019). The threshold effect between the soil bioavailable molar Se:Cd ratio and the accumulation of Cd in corn (Zea mays L.) from natural Se-Cd rich soils. Science of The Total Environment, 688, 1228-1235. doi:https://doi.org/10.1016/i.scitotenv.2019.06.331

Zhang, Z. H., Chen, C., Wu, Q. Y., Zheng, R., Liu, Q., Ni, J. Z., Hoffmann, P. R., \& Song, G. L. (2016). Selenomethionine reduces the deposition of beta-amyloid plaques by modulating beta-secretase and enhancing selenoenzymatic activity in a mouse model of Alzheimer's disease. Metallomics, 8(8), 782789. doi:10.1039/c6mt00117c

Zhao, M., Hou, Y., Fu, X., Li, D., Sun, J., Fu, X., \& Wei, Z. (2018). Selenocystine inhibits JEG-3 cell growth in vitro and in vivo by triggering oxidative damage-mediated S-phase arrest and apoptosis. J Cancer Res Ther, 14(7), 1540-1548. doi:10.4103/jcrt.JCRT_864_17 